\title{
Effect of Copper Source and Level on the Rate and Extent of Copper Repletion in Holstein Heifers ${ }^{1}$
}

\author{
G. P. Yost, ${ }^{\star}$ J. D. Arthington,‡ L. R. McDowell, ${ }^{\star}$ F. G. Martin†, \\ N. S. Wilkinson, ${ }^{*}$ and C. K. Swenson§ \\ *Departments of Animal Sciences and \\ †Statistics, University of Florida-IFAS, \\ Gainesville 32611 \\ †Range Cattle Research and Education Center, \\ Ona, FL 33865, \\ $\S Z$ Zinpro Corporation, \\ Eden Prairie, MN 55344
}

\begin{abstract}
The objective of this study was to evaluate the rate and extent of $\mathrm{Cu}$ repletion in Holstein heifers using two $\mathrm{Cu}$ sources (organic and inorganic) at two levels (15 and $30 \mathrm{mg} / \mathrm{kg}$ ). An additional repletion treatment included a $\mathrm{Cu}$ oxide bolus. Heifers $(\mathrm{n}=50)$ were individually fed a total mixed ration fortified with $\mathrm{S}$ and Mo at $0.40 \%$, and $15 \mathrm{mg} / \mathrm{kg}$ of dry matter of the total diet, respectively. After $111 \mathrm{~d}$ of depletion, heifers were stratified by liver $\mathrm{Cu}$ concentration and randomly allotted to one of five repletion treatments. Four treatments consisted of feed sources of $\mathrm{Cu}$ (feed-Cu), 1) $\mathrm{CuSO}_{4}$ at $\left.15 \mathrm{mg} / \mathrm{kg} ; 2\right) \mathrm{CuSO}_{4}$ at $30 \mathrm{mg} / \mathrm{kg}$; 3) Availa$\mathrm{Cu}$ at $15 \mathrm{mg} / \mathrm{kg}$; and 4) Availa-Cu at $30 \mathrm{mg} / \mathrm{kg}$. Availa$\mathrm{Cu}$ is an organic $\mathrm{Cu}$ source that produces a $\mathrm{Cu}$-amino acid complex. A fifth treatment, consisting of an intraruminal bolus (IB), provided a single dose of $25 \mathrm{~g}$ of $\mathrm{CuO}$ needles. Repletion treatments were delivered in the same total mixed ration without supplemental $\mathrm{S}$ and Mo. Copper status was assessed in blood and liver samples collected on 14-d intervals for $70 \mathrm{~d}$. Irrespective of treatment, all heifers increased in body weight during the repletion period. Liver $\mathrm{Cu}$ increased in each feed-Cu treatment over time. Heifers treated with an IB reached a peak in liver $\mathrm{Cu}$ concentration $(165.5 \mathrm{mg} / \mathrm{kg}$ ) on $\mathrm{d} 28$. Mean liver $\mathrm{Cu}$ concentrations were higher in heifers receiving $30 \mathrm{mg} / \mathrm{kg}$ of $\mathrm{Cu}$ compared with heifers receiving $15 \mathrm{mg} / \mathrm{kg}$ of $\mathrm{Cu}$. Red blood cell superoxide dismutase (SOD) activity was higher $(P<0.001)$ in heifers receiving $\mathrm{CuSO}_{4}$ than Availa-Cu (0.98 vs $0.87 \mathrm{U})$. Also, SOD activity was higher when
\end{abstract}

\footnotetext{
Received March 27, 2002.

Accepted June 6, 2002.

Corresponding author: J. Arthington; e-mail: jarthington@ mail.ifas.ufl.edu.

${ }^{1}$ Contribution No. R-08722 from the Florida Agriculture Experiment Station.
}

heifers were supplemented with 30 vs $15 \mathrm{mg} / \mathrm{kg} \mathrm{Cu}$ ( 0.98 vs $0.87 \mathrm{U}$ ). Heifers receiving the $\mathrm{Cu}$ IB had higher SOD activity than heifers receiving feed-Cu sources (1.03 vs $0.92 \mathrm{U}$ ). Plasma ceruloplasmin concentration was higher $(P<0.001)$ in IB-treated heifers vs. other treatments. No differences in plasma ceruloplasmin were detected for feed-Cu source or level. These results indicate that all $\mathrm{Cu}$ sources evaluated in this study elevated $\mathrm{Cu}$ status of depleted heifers, particularly when provided at higher dietary levels.

(Key words: copper, heifer, repletion)

Abbreviation key: ADG = average daily gain, Feed$\mathbf{C u}=\mathrm{Cu}$-supplemented diets without antagonists, IB = intraruminal bolus, SOD $=\mathrm{Cu}, \mathrm{Zn}$-superoxide dismutase.

\section{INTRODUCTION}

In the past, ruminant $\mathrm{Cu}$ deficiencies have usually been corrected by supplementation with inorganic mineral supplements. Trace minerals complexed with organic molecules have been implied to be more bioavailable than inorganic trace minerals (Brown and Zeringue, 1994). However, a shortcoming of supplemental organic $\mathrm{Cu}$ compounds is their higher cost (Attaelmannan and Reid, 1996). Some researchers (Nockels et al., 1993; Rabiansky et al., 1999) have indicated that $\mathrm{Cu}$ lysine may be more beneficial than $\mathrm{CuSO}_{4}$ in correcting $\mathrm{Cu}$ deficiency in cattle. The physiological advantage afforded by organic $\mathrm{Cu}$ compounds may be due to the unique coordination chemistry of $\mathrm{Cu}$, which permits the formation of highly soluble, chemically stable products that resist digestion and interaction with antagonists in the gut (Brown and Zeringue, 1994).

Other studies (Ward and Spears, 1991; Ward et al., 1993) have shown that $\mathrm{Cu}$ availability from $\mathrm{Cu}$ lysine and $\mathrm{CuSO}_{4}$ were comparable in cattle. Similarly, Kegley and Spears (1994) reported that the $\mathrm{Cu}$ status of 
calves fed $\mathrm{CuSO}_{4}$ did not differ from calves fed $\mathrm{Cu}$ lysine; however, feed-grade $\mathrm{CuO}$ powder did not improve the status of $\mathrm{Cu}$ deficient calves.

An intraruminal bolus (IB) containing $\mathrm{CuO}$ needles is another method that provides long-term supplementation through the slow release of $\mathrm{Cu}$ over an extended period. Cameron et al. (1989) reported significant increases in liver $\mathrm{Cu}$ concentration after $\mathrm{CuO}$ bolus administration in cattle consuming high-Mo forage and high- $\mathrm{SO}_{4}$ water. Although administration of a $\mathrm{CuO}$ bolus effectively elevated the liver $\mathrm{Cu}$ concentration of Cu-deficient cows, Arthington et al. (1995b) reported significant reductions in average daily gain (ADG) and weaning weight of calves that received boluses.

The present study was designed to compare the efficacy of Availa-Cu 100 (Zinpro Corp., Eden Prairie, $\mathrm{MN}$ ), an organic $\mathrm{Cu}$ source that produces a $\mathrm{Cu}-\mathrm{AA}$ complex, $\mathrm{CuSO}_{4}$, and a $\mathrm{CuO}$-containing bolus on the rate and extent of $\mathrm{Cu}$ repletion in $\mathrm{Cu}$-deficient $\mathrm{Hol}$ stein heifers.

\section{MATERIALS AND METHODS}

The University of Florida Animal Care and Use Committee approved the handling and sampling of animals in this experiment (\#A486). Sixty-three 8- to 10-mo-old Holstein heifers from a northwest Florida dairy were received at the University of Florida Beef Research Unit. Upon arrival, heifers were weighed and vaccinated for Clostridia (Fortress 7, Pfizer Animal Health, Exton, PA), IBR, PI3, BVD, BRSV, Leptospira (Cattlemaster 4 L5, Pfizer Animal Health, Exton, PA), and Brucella abortus (Professional Biologicals Co., Denver, CO). Heifers had an average initial BW of $219 \pm 4.8 \mathrm{~kg}$. Heifers were stratified by BW and randomly assigned to one of five pens $\left(100 \mathrm{~m}^{2}\right)$. An adaptation period ( $34 \mathrm{~d}$ ) was allowed to train the heifers to feed individually via electronic Calan gates (American Calan, Northwood, NH). All heifers were provided a basal diet ( $5.45 \mathrm{~kg}$ of $\mathrm{DM} / \mathrm{d})$ consisting of ground corn, soybean meal, cottonseed hulls, and molasses for a 111-d Cu-depletion period followed by a 70-d Cu-repletion period (Table 1). To induce a $\mathrm{Cu}$ deficiency, $\mathrm{S}$ and Mo were provided at $0.40 \%$ of the total diet, and $15 \mathrm{mg} / \mathrm{kg}(\mathrm{Cu}: \mathrm{Mo}=1: 3)$, as flowers of $\mathrm{S}$ and $\mathrm{Na}_{2} \mathrm{MoO}_{4}$, respectively. From d 37 of the depletion period until completion of the experiment, a low-quality bermudagrass hay $(4.6 \mathrm{mg} / \mathrm{kg}$ of $\mathrm{Cu})$ was offered ad libitum due to persistent bloat problems among heifers. Hay consumption was low, but actual intake was not measured. Following depletion, heifers were blocked by liver $\mathrm{Cu}$ concentration and randomly allotted to one of five treatment groups $(\mathrm{n}=10$ heifers/
Table 1. Composition of depletion and repletion diets.

\begin{tabular}{lcc}
\hline Item & Depletion $\operatorname{diet}^{1}$ & ${\text { Repletion } \operatorname{diet}^{1,2}}^{1}$ \\
\cline { 2 - 3 } \% of DM \\
\hline Corn & 55.0 & 60.5 \\
Soybean meal & 16.3 & 15.2 \\
Cottonseed hulls & 19.0 & 15.0 \\
Molasses & 7.0 & 7.0 \\
Limestone & 0.9 & 0.9 \\
Dicalcium phosphate & 0.9 & 0.9 \\
Vitamin/mineral premix & $0.9^{3,4}$ & $0.5^{3}$ \\
\hline
\end{tabular}

${ }^{1}$ Diets fed for 111 and $70 \mathrm{~d}$ for $\mathrm{Cu}$ depletion and repletion, respectively. Diet $\mathrm{DM}=84.8$ and $84.4 \%$ for the $\mathrm{Cu}$ depletion and repletion diets, respectively.

${ }^{2}$ Analyzed $\mathrm{Cu}$ concentration for each repletion diet was 19.48, 29.38, $20.80,40.39$, and $4.81 \mathrm{mg} / \mathrm{kg}$ for $\mathrm{CuSO}_{4}$ at $15 \mathrm{mg} / \mathrm{kg}, \mathrm{CuSO}_{4}$ at 30 $\mathrm{mg} / \mathrm{kg}$, Availa- $\mathrm{Cu}$ at $15 \mathrm{mg} / \mathrm{kg}$, Availa- $\mathrm{Cu}$ at $30 \mathrm{mg} / \mathrm{kg}$, and $\mathrm{CuO}$ bolus, respectively.

${ }^{3}$ Vitamin/mineral premix supplied 50, 0.10, 0.10, 20, and $20 \mathrm{mg} /$ $\mathrm{kg}$ of $\mathrm{Fe}, \mathrm{Se}, \mathrm{Co}, \mathrm{Mn}$, and $\mathrm{Zn}$, respectively. Vitamins A and D were supplied at $8480 \mathrm{IU} / \mathrm{d}$ and $1320 \mathrm{IU} / \mathrm{d}$, respectively.

${ }^{4}$ Fortified with flowers of S to provide a dietary S level of $0.40 \%$ and $15 \mathrm{mg} / \mathrm{kg}$ of $\mathrm{Mo}$ as $\mathrm{Na}_{2} \mathrm{MoO}_{4}$ to achieve a Cu:Mo ratio of 1:3. Copper concentration of depletion diet was $5.50 \mathrm{mg} / \mathrm{kg}$.

treatment). During repletion, heifers received $\mathrm{Cu}$ supplementation diets without antagonists (Feed-Cu): 1) $15 \mathrm{mg} / \mathrm{kg}$ of $\mathrm{Cu}$ from $\mathrm{CuSO}_{4}$; 2) $30 \mathrm{mg} / \mathrm{kg}$ of $\mathrm{Cu}$ from $\mathrm{CuSO}_{4}$; 3) $15 \mathrm{mg} / \mathrm{kg}$ of $\mathrm{Cu}$ from Availa-Cu; and 4) 30 $\mathrm{mg} / \mathrm{kg}$ of $\mathrm{Cu}$ from Availa-Cu. Availa-Cu (Zinpro Corporation) is an organic $\mathrm{Cu}$ source derived from a manufacturing process that produces a $\mathrm{Cu}-\mathrm{AA}$ complex in a metal:AA complex ratio of 1:1. Seventeen different free AA are available to participate in this complex. A fifth treatment provided heifers with a single $25-\mathrm{g}$ dose of $\mathrm{CuO}$ needles via an IB (Copasure, Animax Ltd., Columbus, $\mathrm{OH}$ ). These heifers received the basal diet without any additional supplemental copper.

Heifers were weighed on $\mathrm{d} 0,14,56$, and 70 of $\mathrm{Cu}$ repletion. Liver biopsy samples were collected on $\mathrm{d} 0$, 42,70 , and 111 of the depletion period, and d $0,14,28$, 42,56 , and 70 of the repletion period using a standard procedure (Arthington et al., 1995a). Following each collection, samples were frozen and sent to Michigan State University (Animal Health Diagnostic Laboratory, Lansing) for analysis. Liver samples were digested and subsequently analyzed by inductively coupled plasma-atomic emission spectroscopy as described by Braselton et al. (1997).

Jugular blood was collected by venipuncture into heparinized evacuated tubes on d $0,14,28,42,56$, and 70 of the repletion period. Blood samples were prepared and analyzed at the University of Florida Animal Nutrition Laboratory. Plasma for mineral and ceruloplasmin analyses was harvested following centrifugation at room temperature for $25 \mathrm{~min}$ at $2400 \times$ g. After plasma removal, red blood cell lysate for $\mathrm{Cu}$, 
COPPER REPLETION IN HEIFERS

Table 2. Effect of $\mathrm{Cu}$ source and level on weight gain in heifers during $\mathrm{Cu}$ repletion. ${ }^{1}$

\begin{tabular}{|c|c|c|c|c|c|c|}
\hline \multirow[b]{2}{*}{ Item } & \multicolumn{2}{|c|}{$\begin{array}{c}\mathrm{CuSO}_{4} \\
(\mathrm{mg} / \mathrm{kg})\end{array}$} & \multicolumn{2}{|c|}{$\begin{array}{l}\text { Availa-Cu } \\
(\mathrm{mg} / \mathrm{kg})\end{array}$} & \multirow[b]{2}{*}{$\mathrm{CuO}$ bolus } & \multirow[b]{2}{*}{ SEM } \\
\hline & 15 & 30 & 15 & 30 & & \\
\hline \multicolumn{7}{|l|}{ BW } \\
\hline Initial & 334.7 & 336.1 & 326.3 & 327.8 & 343.6 & 2.8 \\
\hline Final & 400.0 & 409.3 & 396.3 & 403.7 & 409.1 & 2.8 \\
\hline 70-d gain & 65.3 & 73.2 & 70.1 & 75.9 & 65.4 & 4.9 \\
\hline 70-d ADG & 0.93 & 1.05 & 1.00 & 1.08 & 0.93 & 0.07 \\
\hline
\end{tabular}

${ }^{1}$ Single-df contrasts are source $\left(\mathrm{CuSO}_{4}\right.$ vs Availa-Cu; $\left.P=0.48\right)$, level (15 vs. $\left.30 \mathrm{mg} / \mathrm{kg} ; P=0.16\right)$, and feed sources of $\mathrm{Cu}\left(\mathrm{CuSO}_{4}\right.$ and Availa-Cu) vs a single 25 -g dose of $\mathrm{CuO}$ by intraruminal bolus $(P=0.24)$.

Zn-superoxide dismutase (SOD) analysis was collected as described by Disilvestro and Marten (1990) on d $14,28,42$, and 70 . Lysate and plasma samples were placed in a $-20^{\circ} \mathrm{C}$ freezer until they were analyzed. Stored plasma samples were thawed and diluted with 1:1 (vol:vol) deionized water via the method described by Miles et al. (2001). Plasma Cu concentration was determined by atomic absorption spectrophotometry (Perkin-Elmer AAS 5000, Wellesley, MA). Plasma ceruloplasmin activity was determined by spectrophotometric measurement of the colored products formed by the oxidation of $p$-phenylenediamine as described by Demetriou et al. (1974). The activity of erythrocyte SOD was determined by the method originally described by Prohaska (1983) and modified by Percival (1993). Results are expressed as units of SOD activity. One unit of SOD activity is the amount of sample required to inhibit pyrogallol autooxidation by $50 \%$.

Data were analyzed by ANOVA using PROC GLM of SAS (1985). For all analyses involving repeated measures over time, a split-plot design was used with animal serving as the whole plot and time as the subplot. The model included the effects of treatment, time, and the time $\times$ treatment interaction. Treatment means were compared using single-degree of freedom orthogonal contrasts: $\mathrm{CuSO}_{4}$ vs Availa-Cu (source), 15 $\mathrm{mg} / \mathrm{kg}$ vs $30 \mathrm{mg} / \mathrm{kg}$ (level), and all feed-Cu sources vs. IB.

\section{RESULTS AND DISCUSSION}

Irrespective of treatment, BW increased similarly in all heifers (Table 2). Previous $\mathrm{Cu}$ supplementation studies with different feed sources and levels of $\mathrm{Cu}$ have yielded similar results. Rabiansky et al. (1999) reported no differences in total gain or ADG in $\mathrm{Cu}$ deficient heifers fed 8 or $16 \mathrm{mg} / \mathrm{kg}$ of $\mathrm{Cu}$ from $\mathrm{CuSO}_{4}$ or $\mathrm{Cu}$ lysine. Engle and Spears (2000) reported no treatment effects on ADG in growing steers fed 20 or $40 \mathrm{mg} / \mathrm{kg}$ of $\mathrm{Cu}$ from $\mathrm{CuSO}_{4}$ or $20 \mathrm{mg} / \mathrm{kg}$ of $\mathrm{Cu}$ from either $\mathrm{Cu}$ citrate, $\mathrm{Cu}$ proteinate, or $\mathrm{Cu}$ chloride in a corn silage-soybean meal-based diet; however, $\mathrm{Cu}$ supplementation did reduce gain and feed efficiency in the same steers during the finishing phase of the experiment.

Liver $\mathrm{Cu}$ concentration decreased during the $\mathrm{Cu}$ depletion period $(133,64$, and $33 \mathrm{mg} / \mathrm{kg}$ on $\mathrm{d} 0,42$, and 70 of the $\mathrm{Cu}$ depletion period, respectively; SEM $=2.5$ ). The initial liver $\mathrm{Cu}$ concentration on $\mathrm{d} 0$ of the $\mathrm{Cu}$ repletion period was $15 \pm 5 \mathrm{mg} / \mathrm{kg}$ and was similar for all treatments. Underwood and Suttle (1999) indicated that liver $\mathrm{Cu}$ concentrations of 20 to $25 \mathrm{mg} /$ $\mathrm{kg}$ or less were indicative of $\mathrm{Cu}$ deficiency. Liver $\mathrm{Cu}$ concentration increased $(P<0.01)$ over time during the repletion period (Figure 1). Liver $\mathrm{Cu}$ concentration for each feed-Cu treatment increased $(P<0.01)$ linearly throughout the repletion period. Similar increases in liver $\mathrm{Cu}$ concentration over time have been reported in cattle supplied feed sources of $\mathrm{Cu}$ (Arthington et al., 1995a). Stoszek et al. (1986) reported that supple-

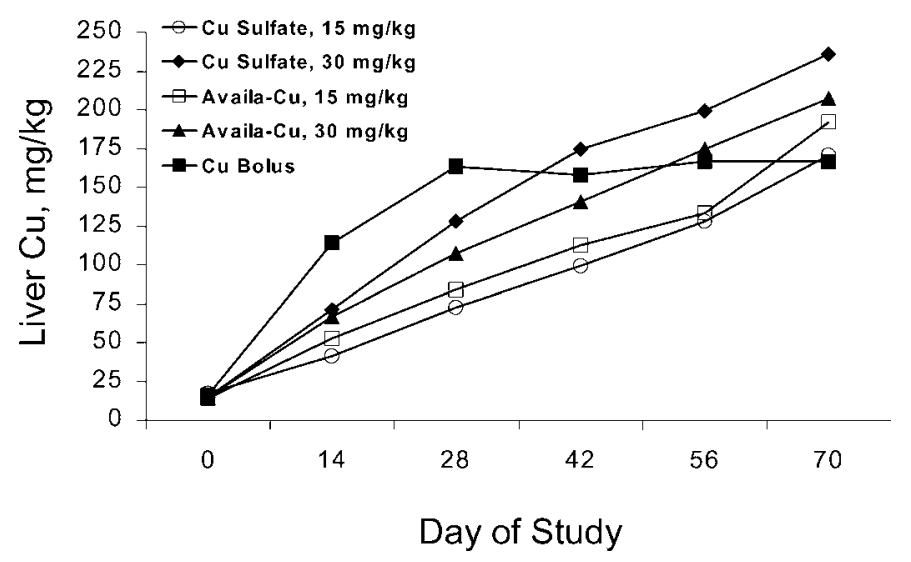

Figure 1. Effect of $\mathrm{Cu}$ source and level on liver $\mathrm{Cu}$ concentration. Pooled SEM $=12 \mathrm{mg} / \mathrm{kg}$. Liver Cu concentration was higher $(P<$ 0.05 ) in heifers treated with a $25-\mathrm{g}$ dose of $\mathrm{CuO}$ by intraruminal bolus than all heifers given feed sources of $\mathrm{Cu}$ on $\mathrm{d} 14$ and 28. Mean liver $\mathrm{Cu}$ concentration over all times was higher $(P<0.01)$ in heifers fed 30 vs $15 \mathrm{mg} / \mathrm{kg}$ of $\mathrm{Cu}$. 
mentation of 300 to $400 \mathrm{mg}$ of $\mathrm{Cu} / \mathrm{d}$ to $\mathrm{Cu}$-deficient cattle rapidly increased liver $\mathrm{Cu}$ stores to normal levels. Liver $\mathrm{Cu}$ concentration in heifers given a $\mathrm{Cu} \mathrm{IB}$ peaked $(163 \pm 12 \mathrm{mg} / \mathrm{kg})$ on d 28 and was higher $(P<$ 0.05 ) than all feed-Cu treatments on $\mathrm{d} 14$ and 28 (Figure 1). Liver $\mathrm{Cu}$ concentration was higher $(P<0.01)$ on $\mathrm{d} 28,42,56$, and 70 in heifers fed $30 \mathrm{mg} / \mathrm{kg}$ of $\mathrm{Cu}$ from $\mathrm{CuSO}_{4}$ than either source at $15 \mathrm{mg} / \mathrm{kg}$ of $\mathrm{Cu}$, but not in heifers fed Availa-Cu at $30 \mathrm{mg} / \mathrm{kg}$. On d 28 and all subsequent sampling dates, liver $\mathrm{Cu}$ concentration in heifers fed $30 \mathrm{mg} / \mathrm{kg}$ of $\mathrm{Cu}$ from Availa-Cu was higher $(P<0.05)$ than heifers fed $15 \mathrm{mg} / \mathrm{kg}$ of $\mathrm{Cu}$ from $\mathrm{CuSO}_{4}$. Similar to the current study, Rabiansky et al. (1999) reported that liver $\mathrm{Cu}$ concentration in heifers fed $16 \mathrm{mg} / \mathrm{kg}$ of $\mathrm{Cu}$ from $\mathrm{CuSO}_{4}$ and $\mathrm{Cu}$ lysine was similar.

Organic $\mathrm{Cu}$ sources have been shown to have higher bioavailability. Nockels et al. (1993) reported greater apparent $\mathrm{Cu}$ absorption and retention of organic $\mathrm{Cu}$ compounds compared with $\mathrm{CuSO}_{4}$ in calves following an 18-d stress period that included ACTH injections and mineral restriction. Du et al. (1996) reported a higher concentration of liver $\mathrm{Cu}$ in rats fed $\mathrm{Cu}$ proteinate vs. $\mathrm{CuSO}_{4}$. In the current study, liver $\mathrm{Cu}$ concentration was not affected by dietary source. Other authors (Wittenberg et al., 1990; Ward et al., 1996) have reported no differences in liver $\mathrm{Cu}$ concentration between inorganic and organic sources. While using $\mathrm{Cu}-$ depleted steers receiving $10 \mathrm{mg} / \mathrm{kg}$ of added Mo, Wittenberg et al. (1990) found that steers fed Cu proteinate had similar liver $\mathrm{Cu}$ concentrations compared with steers fed $\mathrm{CuSO}_{4}$. Ward et al. (1996) used a $\mathrm{S}$ and $\mathrm{Na}_{2} \mathrm{MoO}_{4}$ supplementation strategy similar to the current study to deplete heifers of $\mathrm{Cu}$ and found similar results; liver $\mathrm{Cu}$ concentration of heifers was not different when equal amounts of $\mathrm{Cu}$ proteinate and $\mathrm{CuSO}_{4}$ were fed.

Feeding a Cu level of $30 \mathrm{mg} / \mathrm{kg}$ resulted in a higher $(P<0.01)$ mean liver $\mathrm{Cu}$ concentration compared with $15 \mathrm{mg} / \mathrm{kg}$ (Figure 1). Eckert et al. (1999) reported that liver $\mathrm{Cu}$ concentration in ewes decreased with higher levels of $\mathrm{Cu}$ proteinate, and increased with higher levels of $\mathrm{CuSO}_{4}$. In the current study, liver Cu concentration increased regardless of supplemental $\mathrm{Cu}$ source. The ewes in the study by Eckert et al. (1999) had previously received a Cu-sufficient diet without antagonists and had adequate liver $\mathrm{Cu}$ concentrations before receiving the $\mathrm{Cu}$ supplements. In contrast, heifers in the current study were initially $\mathrm{Cu}$ deficient.

In the current study, $20 \mathrm{~g}$ of $\mathrm{Cu}$ was delivered by the 25-g CuO bolus. A sharp increase in liver $\mathrm{Cu}$ concentration in IB-treated heifers had occurred by d 14, peaking by d 28. Dunbar et al. (1993) reported a peak in liver $\mathrm{Cu}$ concentration around $91 \mathrm{~d}$. The discrepancy in time to peak liver $\mathrm{Cu}$ concentration between the two studies may be due either to the difference in initial $\mathrm{Cu}$ status or the mass of $\mathrm{Cu}$ offered by the bolus. The heifers used by Dunbar et al. had adequate liver $\mathrm{Cu}$ concentrations before receiving $10 \mathrm{~g}$ of encapsulated $\mathrm{Cu}$-wire particles. In the current study, the rapid increase in liver $\mathrm{Cu}$ concentration by $\mathrm{d} 28$ may have occurred because IB-treated heifers were initially $\mathrm{Cu}$ deficient before bolus administration. The $\mathrm{CuO}$ bolus may provide a readily available form of $\mathrm{Cu}$ when delivered in sufficient quantities to $\mathrm{Cu}$-deficient cattle. The linear increase in liver $\mathrm{Cu}$ concentration in heifers provided feed sources of $\mathrm{Cu}$, compared with IB-treated heifers, might suggest a mechanism in which these sources of $\mathrm{Cu}$ are utilized differently by the animal. However, there are no specific studies that show differences in liver $\mathrm{Cu}$ concentration over time when feed source and level of $\mathrm{Cu}$ are compared with $\mathrm{CuO}$ boluses. In the current study, the feed-Cu sources provided a relatively small daily amount of $\mathrm{Cu}(0.08$ and $0.16 \mathrm{~g}$ of $\mathrm{Cu} / \mathrm{d}$ for heifers provided 15 and $30 \mathrm{mg} / \mathrm{kg}$ of $\mathrm{Cu}$, respectively), $<1 \%$ of the amount of $\mathrm{Cu}$ initially delivered by the $\mathrm{CuO}$ bolus. Stoszek et al. (1986) reported that higher supplemental levels of $\mathrm{Cu}(<400 \mathrm{mg}$ of $\mathrm{Cu} /$ d) result in only slight additional increases in liver $\mathrm{Cu}$ concentration in cattle compared with lower supplemental levels. These authors indicated that once physiologically desirable liver $\mathrm{Cu}$ concentrations were reached, a Cu-absorption blocking or excretory mechanism might exist. Ward et al. (1996) reported that $\mathrm{CuCO}_{3}$ was successful in maintaining plasma $\mathrm{Cu}$ and ceruloplasmin activity but was not as efficiently stored in the liver as $\mathrm{CuSO}_{4}$ and an organic $\mathrm{Cu}$ source $(\mathrm{Cu}$ proteinate). Arthington and Brown (2001) reported increases in liver $\mathrm{Cu}$, along with concurrent increases in fecal $\mathrm{Cu}, 12$ and $33 \mathrm{~d}$ after administration of a $\mathrm{CuO}$ bolus. The plateau in liver $\mathrm{Cu}$ concentration in IBtreated heifers after d 28 may be a result of homeostatic regulation of $\mathrm{Cu}$ absorption from $\mathrm{CuO}$ needles when sufficient liver $\mathrm{Cu}$ concentrations are obtained. The period for which IB treatment is effective in maintaining adequate $\mathrm{Cu}$ status in cattle is uncertain. MacPherson (1984) indicated that $20 \mathrm{~g}$ of $\mathrm{CuO}$ needles provided 11 mo of protection against $\mathrm{Cu}$ deficiency. Dunbar et al. (1993) reported a protection period of $12 \mathrm{mo}$. In the current study, the liver $\mathrm{Cu}$ concentration in IB-treated heifers was at a concentration considered adequate at the end of the repletion period on d 70 .

Average plasma $\mathrm{Cu}$ concentration in $\mathrm{Cu}$-deficient heifers before repletion was $0.29 \pm 0.02 \mathrm{mg} / \mathrm{kg}$ (SEM $=0.02)$. Plasma Cu concentration increased $(P<0.01)$ rapidly during the first $14 \mathrm{~d}$ of repletion, regardless of treatment, with only slight increases after d 14 
Table 3. Effect of $\mathrm{Cu}$ source and level on plasma $\mathrm{Cu}$ concentration during $\mathrm{Cu}$ repletion. ${ }^{1}$

\begin{tabular}{|c|c|c|c|c|c|}
\hline \multirow[b]{2}{*}{ Day } & \multicolumn{2}{|c|}{$\begin{array}{c}\mathrm{CuSO}_{4} \\
(\mathrm{mg} / \mathrm{kg})\end{array}$} & \multicolumn{2}{|c|}{$\begin{array}{c}\text { Availa-Cu } \\
(\mathrm{mg} / \mathrm{kg})\end{array}$} & \multirow[b]{2}{*}{$\mathrm{CuO}$ bolus } \\
\hline & 15 & 30 & 15 & 30 & \\
\hline & & & $\mathrm{mg}$ & & \\
\hline 0 & 0.26 & 0.27 & 0.32 & 0.32 & $\begin{array}{l}0.27 \\
0.88\end{array}$ \\
\hline 14 & 0.75 & 0.81 & 0.89 & 0.79 & 0.88 \\
\hline 28 & 0.84 & 0.79 & 0.88 & 0.84 & 0.85 \\
\hline 42 & 0.87 & 0.97 & 0.92 & 0.89 & 0.95 \\
\hline 56 & 0.79 & 0.80 & 0.82 & 0.85 & 0.88 \\
\hline 70 & 0.86 & 0.93 & 0.88 & 0.96 & 0.97 \\
\hline Mean & 0.73 & 0.76 & 0.79 & 0.78 & 0.80 \\
\hline
\end{tabular}

${ }^{1}$ Single-df contrasts are source $\left(\mathrm{CuSO}_{4}\right.$ vs Availa-Cu; $\left.P=0.24\right)$, level (15 vs $\left.30 \mathrm{mg} / \mathrm{kg} ; P=0.72\right)$, and feed sources of $\mathrm{Cu}\left(\mathrm{CuSO}_{4}\right.$ and Availa-Cu) vs 25 -g single dose of $\mathrm{CuO}$ by intraruminal bolus $(P=0.24)$. Pooled $\mathrm{SEM}=0.04$, based on $36 \mathrm{df}$.

(Table 3). After $\mathrm{Cu}$ depletion, all heifers had plasma and liver $\mathrm{Cu}$ concentrations below 0.40 and $20 \mathrm{mg} /$ $\mathrm{kg}$, respectively. When liver $\mathrm{Cu}$ concentration reached levels $>40 \mathrm{mg} / \mathrm{kg}$ by d 14 , plasma $\mathrm{Cu}$ concentration was variable. The plasma and liver $\mathrm{Cu}$ concentrations in this study correspond with the findings of Claypool et al. (1975). These authors indicated that when liver $\mathrm{Cu}$ levels are $<40 \mathrm{mg} / \mathrm{kg}$, plasma Cu levels are usually $<0.5 \mathrm{mg} / \mathrm{kg}$; however, plasma $\mathrm{Cu}$ levels are highly variable when liver $\mathrm{Cu}$ concentrations are $>40 \mathrm{mg} / \mathrm{kg}$. Plasma $\mathrm{Cu}$ concentration can often be an unreliable indicator of $\mathrm{Cu}$ deficiency, since plasma $\mathrm{Cu}$ concentration increases in cattle exposed to an immune challenge (Nockels et al., 1993). Therefore, plasma Cu concentration should not be the only index used to define $\mathrm{Cu}$ deficiency in cattle (Mulryan and Mason, 1992).

Ceruloplasmin responded in a fashion similar to plasma $\mathrm{Cu}$, in that concentrations increased rapidly by d $14(P<0.01)$, regardless of treatment (Table 4$)$. Similar increases in ceruloplasmin concentration (Rabiansky et al., 1999) and activity (Kegley and
Spears, 1994) over time have been reported in $\mathrm{Cu}-$ deficient cattle fed either $\mathrm{CuSO}_{4}$ or $\mathrm{Cu}$ lysine. In the current study, plasma ceruloplasmin and plasma $\mathrm{Cu}$ concentrations were similar, increasing sharply by $\mathrm{d}$ 14. Mean plasma ceruloplasmin concentration was higher $(P<0.05)$ in IB-treated heifers than all feed$\mathrm{Cu}$ treatments $(22.8$ and $20.6 \mathrm{mg} / \mathrm{dL}$ for IB and feed$\mathrm{Cu}$ treatments, respectively; $\mathrm{SEM}=0.84$ ). The higher ceruloplasmin concentration in IB-treated heifers was likely due to the larger initial amount of $\mathrm{Cu}$ being supplied by the bolus.

Erythrocyte SOD activity increased over time $(P<$ 0.01; Table 5). Heifers fed CuSO4 had higher $(P<$ 0.001) mean SOD activity than did heifers fed Availa$\mathrm{Cu}$. In addition, IB-treated heifers had higher $(P=$ 0.004) mean SOD activity than all feed-Cu treatments (Table 5). We are unable to provide an explanation for these differences. Suttle and McMurray (1983) reported that a temporal relationship between plasma $\mathrm{Cu}$ concentration and erythrocyte SOD might exist and be of diagnostic value when evaluating $\mathrm{Cu}$ status.

Table 4. Effect of $\mathrm{Cu}$ source and level on plasma ceruloplasmin concentration during Cu repletion. ${ }^{1}$

\begin{tabular}{|c|c|c|c|c|c|}
\hline \multirow[b]{2}{*}{ Day } & \multicolumn{2}{|c|}{$\begin{array}{c}\mathrm{CuSO}_{4} \\
(\mathrm{mg} / \mathrm{kg})\end{array}$} & \multicolumn{2}{|c|}{$\begin{array}{c}\text { Availa-Cu } \\
(\mathrm{mg} / \mathrm{kg})\end{array}$} & \multirow[b]{2}{*}{$\mathrm{CuO}$ bolus } \\
\hline & 15 & 30 & 15 & 30 & \\
\hline & & & \multicolumn{2}{|c|}{$\mathrm{mg} / 100 \mathrm{ml}$} & 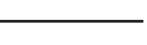 \\
\hline 0 & 5.9 & 9.1 & 10.1 & 7.6 & 7.9 \\
\hline 14 & 19.5 & 20.0 & 21.3 & 18.8 & 23.0 \\
\hline 28 & 23.7 & 20.3 & 21.7 & 21.2 & 21.6 \\
\hline 35 & 24.4 & 25.9 & 24.5 & 22.9 & 27.6 \\
\hline 42 & 21.5 & 23.1 & 23.5 & 23.1 & 25.0 \\
\hline 49 & 21.7 & 23.3 & 23.1 & 24.1 & 25.4 \\
\hline 56 & 23.3 & 25.0 & 23.4 & 24.6 & 29.2 \\
\hline 70 & 27.2 & 25.2 & 27.8 & 27.2 & 30.2 \\
\hline Mean & 20.9 & 21.5 & 21.9 & 21.2 & 23.7 \\
\hline
\end{tabular}

${ }^{1}$ Single-df contrasts are source $\left(\mathrm{CuSO}_{4}\right.$ vs Availa-Cu; $\left.P=0.40\right)$, level (15 vs $\left.30 \mathrm{mg} / \mathrm{kg} ; P=0.93\right)$, and feed sources of $\mathrm{Cu}\left(\mathrm{CuSO}_{4}\right.$ and Availa-Cu $)$ vs a 25 -g single dose of $\mathrm{CuO}$ by intraruminal bolus $(P<0.0001)$. Pooled SEM $=0.92$, based on $36 \mathrm{df}$. 
Table 5. Effect of $\mathrm{Cu}$ source and level on erythrocyte superoxide dismutase activity during $\mathrm{Cu}$ repletion. ${ }^{1}$

\begin{tabular}{|c|c|c|c|c|c|}
\hline \multirow[b]{2}{*}{ Day } & \multicolumn{2}{|c|}{$\begin{array}{c}\mathrm{CuSO}_{4} \\
(\mathrm{mg} / \mathrm{kg})\end{array}$} & \multicolumn{2}{|c|}{$\begin{array}{c}\text { Availa-Cu } \\
(\mathrm{mg} / \mathrm{kg})\end{array}$} & \multirow[b]{2}{*}{$\mathrm{CuO}$ bolus } \\
\hline & 15 & 30 & 15 & 30 & \\
\hline & & & Units of & & - \\
\hline 14 & 0.74 & 0.83 & 0.63 & 0.76 & 0.85 \\
\hline 28 & 0.85 & 0.93 & 0.60 & 0.80 & 0.89 \\
\hline 42 & 0.95 & 1.02 & 0.84 & 0.97 & 0.92 \\
\hline 70 & 1.28 & 1.27 & 1.08 & 1.23 & 1.48 \\
\hline Mean & 0.95 & 1.01 & 0.79 & 0.94 & 1.03 \\
\hline
\end{tabular}

${ }^{1}$ Single-df contrasts are source $\left(\mathrm{CuSO}_{4}\right.$ vs Availa-Cu; $\left.P<0.001\right)$, level (15 vs $\left.30 \mathrm{mg} / \mathrm{kg} ; P<0.002\right)$, and feed sources of feed $\left(\mathrm{CuSO}_{4}\right.$ and Availa-Cu $)$ vs a 25-g single dose of $\mathrm{CuO}$ by intraruminal bolus $(P=0.004)$. Pooled SEM $=0.08$, based on $36 \mathrm{df}$.

These investigators found that erythrocyte SOD concentration reached maximal levels $15 \mathrm{~d}$ after plasma $\mathrm{Cu}$ concentration peaked in ewes supplied $0.5 \mathrm{~g}$ of $\mathrm{Cu}$ as $\mathrm{CuSO}_{4}$ in a gelatin capsule. In the current study, plasma $\mathrm{Cu}$ concentration reached peak values by $\mathrm{d} 14$; however, SOD activity continued to increase up to d 70. The differences in the lag time for peak recovery of plasma $\mathrm{Cu}$ concentration and erythrocyte SOD activity may be the result of several factors. First, the ewes in the Suttle and McMurray (1983) study may have been more severely $\mathrm{Cu}$ deficient than the heifers in the current study prior to repletion. Second, the larger lag time in the current study may be a result of the long erythrocyte life span $(\sim 150 \mathrm{~d})$, or the incorporation of $\mathrm{Cu}$ into SOD at erythropoiesis. Continued sampling beyond $70 \mathrm{~d}$ of supplementation may have provided more insight to the interpretation of these data.

\section{CONCLUSIONS}

Both $\mathrm{CuSO}_{4}$ and Availa-Cu appear equally effective in elevating the $\mathrm{Cu}$ status of $\mathrm{Cu}$-deficient Holstein heifers. Copper supplementation at $30 \mathrm{mg} / \mathrm{kg}$ significantly increased liver $\mathrm{Cu}$ concentration compared with $\mathrm{Cu}$ supplementation at $15 \mathrm{mg} / \mathrm{kg}$. In comparison to feed-Cu sources, administration of the $\mathrm{CuO}$ bolus (one-time dose of $20 \mathrm{~g}$ of $\mathrm{Cu}$ ) resulted in a higher mean plasma ceruloplasmin concentration and a more rapid increase in liver $\mathrm{Cu}$ concentration, which peaked at $\mathrm{d}$ 28 and then plateaued.

\section{REFERENCES}

Arthington, J. D., and W. F. Brown. 2001. The effect of copper oxide bolus administration on forage fiber digestibility in growing steers. J. Anim. Sci. 79(Suppl. 1):422.

Arthington, J. D., L. R. Corah, F. Blecha, and D. A. Hill. 1995a. Effect of copper depletion and repletion on lymphocyte blastogenesis and neutrophil bactericidal function in beef heifers. J. Anim. Sci. 73:2079-2085.
Arthington, J. D., R. L. Larson, and L. R. Corah. 1995b. The effects of slow-release copper boluses on cow reproductive performance and calf growth. Prof. Anim. Scientist 11:219-222.

Attaelmannan, M. A., and R. S. Reid. 1996. The speciation of lysinecomplexed copper as a bovine nutritional supplement. J. Inorg. Biochem. 64:215-224.

Braselton, W. E., K. J. Stuart, T. P. Mullaney, and T. H. Herdt. 1997. Biopsy mineral analysis by inductively coupled plasmaatomic emission spectroscopy with ultrasonic nebulization. J. Vet. Diagn. Invest. 9:395-400.

Brown, T. F., and L. K. Zeringue. 1994. Laboratory evaluations of solubility and structural integrity of complexed and chelated trace mineral supplements. J. Dairy Sci. 77:181-189.

Cameron, H. J., R. J. Boila, L. W. McNichol, and N. E. Stanger. 1989. Cupric oxide needles for grazing cattle consuming lowcopper, high-molybdenum forage and high-sulfate water. J. Anim. Sci. 67:252-261.

Claypool, D. W., F. W. Adams, H. W. Pendell, N. A. Hartmann Jr., and J. F. Bone. 1975. Relationship between the level of copper in the blood plasma and liver of cattle. J. Anim. Sci. 41:911-914.

Demetriou, J. A., P. A. Drews, and J. B. Gin. 1974. Enzymes. Pages 857-864 in Clinical Chemistry. 2nd ed. R. J. Henry, D. C. Cannon, and J. W. Winkelman, ed. Harper and Row, Hagerstown, MD.

Disilvestro, R. A., and J. T. Marten. 1990. Effects of inflammation and copper intake on rat liver and erythrocyte $\mathrm{Cu}-\mathrm{Zn}$ superoxide dismutase activity levels. J. Nutr. 120:1223-1227.

Du, Z., R. W. Hemken, J. A. Jackson, and D. S. Trammell. 1996. Utilization of copper in copper proteinate, copper lysine, and cupric sulfate using the rat as an experimental model. J. Anim. Sci. 74:1657-1663.

Dunbar, J. R., J. G. Morris, B. B. Norman, A. J. Jenkins, C. B. Wilson, and J. M. Connor. 1993. Cupric-oxide needles effective as oral copper supplement in cattle. Calif. Agric. 47:25-26.

Eckert, G. E., L. W. Greene, G. E. Carstens, and W. S. Ramsey. 1999. Copper status of ewes fed increasing amounts of copper from copper sulfate or copper proteinate. J. Anim. Sci. $77: 244-249$.

Engle, T. E., and J. W. Spears. 2000. Effects of dietary copper concentration and source on performance and copper status of growing and finishing steers. J. Anim. Sci. 78:2446-2451.

Kegley, E. B., and J. W. Spears. 1994. Bioavailability of feed-grade copper sources (oxide, sulfate, or lysine) in growing cattle. J. Anim. Sci. 72:2728-2734.

MacPherson, A. 1984. Long term effectiveness of graded doses of copper oxide needles in suckler cows. Vet. Rec. 115:354-355.

Miles, P. H., N. S. Wilkinson, and L. R. McDowell. 2001. Analysis of Minerals for Animal Nutrition Research. 3rd ed. Dept. Anim. Sci., Univ. Florida, Gainesville.

Mulryan, G., and J. Mason. 1992. Assessment of liver copper status in cattle from plasma copper and plasma copper enzymes. Ann. Rech. Vet. 23:233-238. 
Nockels, C. F., J. DeBonis, and J. Torrent. 1993. Stress induction affects copper and zinc balance in calves fed organic and inorganic copper and zinc sources. J. Anim. Sci. 71:2539-2545.

Percival, S. S. 1993. Cu/Zn superoxide dismutase activity does not parallel copper levels in copper supplemented HL-60 cells. Biol. Trace Elem. Res. 38:63-72.

Prohaska, J. R. 1983. Changes in tissue growth, concentration of copper, iron, cytochrome oxidases and superoxide dismutase subsequent to dietary or genetic copper deficiency in mice. J. Nutr. 113:2048-2058.

Rabiansky, P. A., L. R. McDowell, J. Velasquez-Pereira, N. S. Wilkinson, S. S. Percival, F. G. Martin, D. B. Bates, A. B. Johnson, T. R. Batra, and E. Salgado-Madriz. 1999. Evaluating copper lysine and copper sulfate sources for heifers. J. Dairy Sci. 82:2642-2650.

SAS User's Guide: Statistics, Version 5 Edition. 1985. SAS Inst., Inc., Cary, NC.

Stoszek, M. J., P. G. Mika, J. E. Oldfield, and P. H. Weswig. 1986. Influence of copper supplementation on blood and liver copper in cattle fed tall fescue or quackgrass. J. Anim. Sci. 62:263-271.
Suttle, N. F., and C. H. McMurray. 1983. Use of erythrocyte copper:zinc superoxide dismutase activity and hair or fleece copper concentrations in the diagnosis of hypocuprosis in ruminants. Res. Vet. Sci. 35:47-52.

Underwood, E. J., and N. F. Suttle. 1999. Chap. 11 in The Mineral Nutrition of Livestock. CABI Publ., New York, NY.

Ward, J. D., and J. W. Spears. 1991. Availability of copper in ruminants from copper lysine relative to copper sulfate. J. Anim. Sci. 69(Suppl. 1):554.

Ward, J. D., J. W. Spears, and E. B. Kegley. 1993. Effect of copper level and source (copper lysine vs copper sulfate) on copper status, performance, and immune response in growing steers fed diets with or without supplemental molybdenum and sulfur. J. Anim. Sci. 71:2748-2755.

Ward, J. D., J. W. Spears, and E. B. Kegley. 1996. Bioavailability of copper proteinate and copper carbonate relative to copper sulfate in cattle. J. Dairy Sci. 79:127-132.

Wittenberg, K. M., R. J. Boila, and M. A. Shariff. 1990. Comparison of copper sulfate and copper proteinate as copper sources for copper-depleted steers fed high molybdenum diets. Can. J. Anim. Sci. 70:895-904. 